Świętego. Prelegent ukazał konkretne przykłady z tradycji biblijnej mówiące o podejmowaniu zadań pomocowych względem rodziny, a zwłaszcza wobec wdów, sierot, ubogich i obcokrajowców.

Konferencję zakończyło podsumowanie obrad, w którym zasygnalizowano główne tezy poszczególnych wystąpień, a także zwrócono uwagę na znaczenie interdyscyplinarnego ujmowania problematyki wspierania rodziny.

Agnieszka Regulska - WSR UKSW, Warszawa

\title{
„Etyczne aspekty edukacji seksualnej w wieku dziecięcym”. Sprawozdanie z międzynarodowej konferencji naukowej zorganizowanej przez Stowarzyszenie Bioetyków Centralnej Europy. Wiedeń, 23-25 października 2015 r.
}

W dniach od 23 do 25 października 2015 r. w Wiedniu odbyła się 9. międzynarodowa konferencja naukowa zorganizowana przez Stowarzyszenie Bioetyków Centralnej Europy (BCE - Association of Bioethicists in Central Europe). Tegoroczne obrady, które przebiegały pod hasłem Etyczne aspekty edukacji seksualnej w wieku dziecięcym, zgromadziły około 60. uczestników. Wśród nich znaleźli się przede wszystkim teologowie moraliści z Europy Środkowej i Wschodniej (m.in. z Polski, Austrii, Niemiec, Czech, Słowacji, Węgier, Chorwacji i Słowenii).

Sympozjum rozpoczęło się od wykładu Przegląd współczesnych koncepcji wychowania seksualnego, który wygłosił dr Karlheinz Valtl z Uniwersytetu Wiedeńskiego. Prelekcja miała charakter wprowadzający. Wykładowca wskazał na istnienie różnych kryteriów określania płci, które opierają się na wskaźnikach anatomicznych, genetycznych i kulturowych. Omówił także podstawowe zagadnienia, które obejmuje naukowa refleksja nad wychowaniem seksualnym, czyli ciało człowieka, jego budowa i funkcje, edukacja seksualna, język i sposób mówienia na temat seksualności, identyfikacja płciowa, nadużycia seksualne oraz wybrane kwestie etyczne. Prelegent podkreślił także, że edukacją seksualną należy objąć wszystkie dzieci niemalże od momentu ich przyjścia na świat. Stwierdzenie to spotkało się z licznymi głosami sprzeciwu. Wskazano w nich, że zakres przekazywanej wiedzy powinien być dostosowany do poznawczych możliwości dziecka oraz jego rozwoju emocjonalnego i duchowego.

Kolejny wykład Psychoseksualny rozwój dziecka zaprezentował prof. dr Jochen Sautermeisterzwiązany z Uniwersytetem w Monachium. Wskazał, że seksualność jest jedną z podstawowych dyspozycji człowieka i stanowi fenomen biologiczno-psychiczno-społeczny obejmujący relacje, motywacje, normy i zachowania. 
Ta wielowymiarowa rzeczywistość jest z kolei związana z licznymi funkcjami. Prelegent ukazał także fazy psychoseksualnego rozwoju dziecka, który swój początek ma w określeniu chromosomalnym dokonującym się w momencie połączenia się komórki jajowej z plemnikiem. Omówiona została także koncepcja Zygmunta Freuda. Prof. Sautermeister odniósł się także do wyzwań moralno-pedagogicznych. Podkreślił potrzebę właściwej komunikacji. W nawiązaniu do ożywionej dyskusji po pierwszym wykładzie wskazał na konieczność dostosowania zakresu edukacji do wieku dziecka, aby potrafiło ono właściwie interpretować poszczególne zachowania w sferze seksualnej.

Ostatnia prelekcja Wychowanie seksualne z perspektywy europejskiej na przykładzie standardów $W H O$ została wygłoszona przez Olafa Kapella, który pracuje w Austriackim Instytucie Studiów nad Rodziną. Jego zdaniem, dyskusja na temat edukacji jest efektem rewolucji seksualnej, a głównymi faktorami jej rozwoju są nadużycia seksualne, powstanie nowych środków społecznego przekazu oraz rezygnacja z propagowania całkowitej abstynencji seksualnej wśród dzieci i młodzieży. Omówione zostały także główne idee wskazań Światowej Organizacji Zdrowia. W ich świetle seksualność rozumiana jest wyłącznie w wymiarze cielesnym, a edukacją będąca elementem praw seksualnych i reprodukcyjnych _winna być prowadzona od urodzenia i obejmować sferę wiedzy, umiejętności oraz postaw.

Niezwykle cennym momentem była praca w małych grupach. Uczestnicy konferencji pod kierunkiem wyznaczonych moderatorów zastanawiali się m.in. nad wybranymi aspektami ideologii gender, rolą wychowania seksualnego w przeciwdziałaniu nadużyciom oraz wpływem nowych mediów i potrzebą formowania osób odpowiedzialnych za ich funkcjonowanie.

Doroczny zjazd Stowarzyszenia Bioetyków Centralnej Europy był także okazją do planowania dalszej działalności naukowej. Ustalono, że przyszłoroczna konferencja odbędzie się w Pradze, a za dwa lata sympozjum będzie miało miejsce ponownie w Wiedniu. Wybór tematyki powierzono zarządowi Stowarzyszenia. Odbyło się także spotkanie koordynatorów międzynarodowego programu wymiany studentów i pracowników naukowych CEEPUS.

Udział w konferencji był szczególnie cenny dla reprezentantów polskiego środowiska teologów moralistów. Pozwolił bowiem zapoznać się z doświadczeniem krajów, w których edukacja seksualna jest prowadzona już od dłuższego czasu. To pozwala z kolei na wyciągnięcie rzetelnych wniosków, które nie napawają optymizmem. Niejednokrotnie bowiem edukacja ta przynosi dramatyczne skutki dla życia rodzinnego. Ma negatywny wpływ przede wszystkim na integralny rozwój psychoseksualny dzieci oraz przyczynia się do ukształtowania postaw permisywnych w społeczeństwie. Taka wymiana poglądów i wniosków stanowić 
będzie zapewne cenną pomoc we włączeniu się w toczącą się w Polsce debatę na temat edukacji seksualnej dzieci i młodzieży.

ks. Krzysztof Smykowski - WT KUL Lublin

\begin{abstract}
„Praca socjalna: Kształcenie. Profesja. Dyscyplina naukowa”. Sprawozdanie z ogólnopolskiej konferencji (seminarium naukowego) zorganizowanej przez Polskie Stowarzyszenie Szkól Pracy Socjalnej i Instytut Socjologii Uniwersytetu Kardynała Stefana Wyszyńskiego w Warszawie 22-23 października 2015 r.
\end{abstract}

Ta cykliczna konferencja naukowa jest corocznie organizowana w innym ośrodku akademickim przez Polskie Stowarzyszenie Szkół Pracy Socjalnej. W roku 2015 był to Uniwersytet Kardynała Stefana Wyszyńskiego w Warszawie, na którym od 20 lat przygotowywani są kandydaci do pracy w zawodzie pracownika socjalnego. Od 25 lat konferencja powiązana jest ze zjazdem członków Stowarzyszenia, zatem to spotkanie miało charakter jubileuszowy. Całość spotkania rozpoczęła się 21.10.2015 r. od Zebrania Zarządu Polskiego Stowarzyszenia Szkół Pracy Socjalnej. Zebranie to miało miejsce w Hotelu Holiday Park, przy ul. Heroldów lb w Warszawie na Bielanach. W trakcie spotkania zarządu omówiono rok pracy oraz przygotowano wybory nowego zarządu Stowarzyszenia. Z racji, że UPJPII nie jest członkiem Stowarzyszenia, nie uczestniczył w spotkaniu żaden z pracowników naukowych papieskiej Uczelni.

Jubileuszowa, XXV Konferencja naukowa rozpoczęła się dnia następnego 22.10.2015r., w Auli im. Roberta Szumana, w budynku Auditorium Maximum UKSW, przy ul. Wóycickiego 1/3 w Warszawie. Uroczystą część inaugurującą konferencję prowadził Dziekan Wydziału Historycznego i Społecznego UKSW, dr hab. Tadeusz Kamiński. Otwarcia seminarium dokonał w imieniu rektora UKSW ks. prof. dra hab. Stanisława Dziekońskiego - prorektor ds. finansowych i infrastruktury, prof. dr hab. Jerzy Cytowski. Następnie przywitała wszystkich zebranych prezes PSSPS, dr hab. Anna Michalska, prof. UAM. W części wprowadzającej głos zabrał dr hab. Hubert Kaszyński - pracownik UJ i UPJPII. Wystąpił jako członek CKA zajmującej się pracą socjalną, wskazał nowe wymagania ustawowe ogniskujące pracę pracownika socjalnego na superwizji i projekcie socjalnym. Według mówcy wymagania ustawowe stanowią wyzwanie i konieczność zmiany akcentów w kształceniu pracowników socjalnych. Rangę spotkania podniósł także głos przedstawicielki rządu RP mówiącej o konieczności szkolenia superwizorów w ramach doskonalenia zawodowego pracowników socjalnych. 